\title{
Determinants of Value Added Tax Collection Performance in West Shoa Zone, Oromia Regional State, Ethiopia
}

\author{
Aduna Tajebe Leta Ayana Gemechu Bultum \\ Ambo University, College of Business \& Economics, Department of Accounting \& Finance
}

\begin{abstract}
The study was conducted to investigate the determinant factors of Value Added Tax collection performance in West Shoa Zone by giving emphasis on three selected districts i.e. Ambo city Revenues Authority, Dandi and Bako woredas Revenues Authority's. The researchers used cross-sectional data covering a period in 2017. Since the data was survey in nature the researcher used both qualitative and quantitative (Mixed) research approaches to achieve objective of the study. The researchers used purposive and stratified sampling method to take a sample of Tax payers, Consumers and Revenues Authority Employees. Descriptive statistics and multiple regressions were used to analyze primary and secondary data to reach the result of the study using Statistical Package for Social Science (SPSS) version 20. The result of the study showed that Tax payers awareness on Value added Tax, Tax payers' maintenance of account and Value added Tax Rate have positively influenced Value added Tax collection performance whereas Tax Evasion, Tax avoidance and Tax non-compliance variables have negatively affected Value added Tax collection performance for tax payers. The study results also showed that Value added Tax Assessment, Value added Tax Audit, Competence training, Adequate manpower, Tax payers identification and Penalization variables have positively influenced Value added Tax collection performance whereas External Legal Environment variable negatively affected Value added Tax collection performance for institutional variables. Thus, it's recommended that Revenues Authority should fulfill necessary manpower and create continuous follow up in order to improve Value added Tax collection performance.
\end{abstract}

Keywords: Value added Tax, Tax avoidance, Tax Evasion, performance, Tax payers

DOI: $10.7176 /$ RJFA/10-21-06

Publication date: November $30^{\text {th }} 2019$

\section{Introduction}

Value Added Tax (VAT) is a tax on the value added to goods and services by enterprises at each stage of the production and distribution processes. It arises whenever a "taxable person" makes a "supply of goods or services" in the course of his business. Thus, in some countries, it is called "goods and services tax" or GST. Value added tax was invented because very high sales taxes and tariffs encourage cheating and smuggling (Worku, 2008). Value added tax - has spread throughout the world since its introduction in 1955. France was the first country to introduce VAT effective from April 10, 1954. By 1969, only eight nations had adopted VAT, out of this Cote-Devoir was the first country in Africa to introduce VAT in 1960. Since 1979 VAT has been adopted as the main form of an indirect tax by many countries in different parts of the world. (Misrak, 2008). The Ethiopian government has replaced the former sales tax to make the tax administration more efficient in line with this the Federal Democratic Republic of Ethiopia (FDRE) has adopted VAT into its tax system on January 1, 2003 by replacing the former sales tax system. Therefore multi stage sales tax which is imposed at more than one level of production and distribution has replaced sales tax for reasons of administration and simplicity. (Hailu, 2004).

The Main reasons for introducing VAT were to broaden the tax base, to attain economic neutrality, to promote exports, and to attain its administrative advantages. Further, since its introduction, VAT has been more revenue productive than sales tax (Tefera, 2004). To sustain VAT"s revenue role in the government's finance, it is important to ensure that the revenue generated by this tax is raised efficiently as possible. The inadequate revenue performance of VAT may be caused by factors including poor VAT administration, i.e., the incapacity of tax authorities to implement the attributes of the tax in practice. A good tax administration is essential in fully implementing the design features of VAT and achieving government's policy at large (Mikesell, 2007).

According to Hailu (2004), VAT is a tax levy on consumption of goods and services. Moreover, it is a modified sales tax based on the net value added at each stage of production or services rather than on gross receipts. The VAT system is believed to encourage savings, exports and capital accumulations as it is levied on goods and services meant for consumption. Apart from this the VAT is charged on taxpayers that meet the threshold of Ethiopian Birr (ETB) 1 million and above in annual turnover and the tax is charged at $15 \%$ rate on transactions subject to VAT. VAT is the major source of income from indirect tax in west Shoa Zone since its introduction. But, in practice, value added Tax collected to VAT target was not geared with its plan. This is due to Value added tax problems particularly for key VAT administrative functions, Tax payers and Consumers. Keeping this in mind, this study was intended to investigate the Determinant factors of Value Added Tax 
collection performance in West Shoa Zone.

\section{Literature Review}

\subsection{Theoretical Literature}

This part presents relevant theories about indirect taxes. The economists have put forward many theories of taxation at different times to guide the state as to how justice or equity in taxation can be achieved.

\section{The Benefit Theory}

This theory holds the individuals should be taxed in proportion to the benefits they receive from the governments in public services and that taxes should be paid by those people who receive the direct benefit of the government programs and projects out of the taxes paid. It was developed in the seventeenth century by English philosophers Thomas Hobbes (1588-1679) and John Locke (1632-1704), and Dutch jurist Hugo Grotius (1583-1645) (Saleemi, 2005).

\section{The Ability-to-Pay Theory}

This theory originates from the sixteenth century. It was scientifically extended by the Swiss philosopher Jean Jacques Rousseau (1712-1778), the French political economist Jean-Baptiste Say (1767-1832) and the English economist John Stuart Mill (1806-1873). This theory holds that the taxation should be levied according to an individual's income or ability to pay and is the basis of progressive tax as the tax rate increases by the increase of the taxable amount (Jones \& Rhoades, 2011).

\section{The Cost of Service theory}

The cost of service theory can no doubt be applied to some extent in those cases where the services are rendered out of prices and are a bit easy to determine, e.g., postal, railway services, supply of electricity, etc., But most of the expenditure incurred by the state cannot be fixed for each individual because it cannot be exactly determined, for instance, the cost of service of the police, armed forces, judiciary, etc., to different individuals. Dalton has also rejected this theory on the ground that there is no quid pro qua in a tax (Kaplow, 2010).

\section{VAT Revenue Performance}

Traditionally, the effectiveness of VAT in raising revenue is measured by the ratio of VAT revenue to GDP. Countries with similar standard of VAT rate can have significant different ratio of VAT revenue to GDP. More generally, the efficiency ratio as defined by (Ebrill and \& Keen, 2001) as the ratio of VAT revenues to GDP divided by the standard VAT rate. It has been used as a general indicator of the performance of VAT. They found that in the countries adopting VAT, revenue from this source accounted on average 27 percent of the total tax revenue or $5 \%$ of the GDP. And about $70 \%$ of the world's populations now live in countries with a VAT. This implies that it is a key source of government revenue in more than 126 nations. Moreover, International Monetary fund (IMF) report (2004), shows that more than 4billion, 70\%, of the world's population now live in countries with VAT and VAT raises about $\$ 18$ trillion in tax revenue, roughly one-quarter of all government revenue. Nowadays, among 190 countries of the world, over $136(72 \%)$ of them have made VAT part of their tax system; and from 53 members of countries of Africa Union, 33 (60\%) of them have introduced VAT.

\section{Awareness level of Taxpayers}

James (2000) argues that Many taxpayers might be willing to comply tax in full, but are unable to do so because they are not aware of, or do not understand, their full obligations. Even if such tax payers understand their obligations, they may not know how to meet them or may be unable to do so for other reasons. Consciousness or awareness is the human element in the understanding of reality and how to react or respond to the reality. Awareness includes self-awareness, self-fellow, past, and their future possibilities. Public awareness of taxation means that taxpayers want to pay taxes because they are not disadvantaged in the tax collection. However, tax awareness is often an obstacle or problem to collect the taxes from the society. Many people who do not know the concrete form of compensation for the tax they have paid (Santi, 2012).

\section{Employee Training}

Improving efficiency and performance to ensure that the organization is capable of responding program but in striving for enhanced efficiency and levels of performance, training should also be seen as a part of individual professional development. An organization can increase the likelihood that will keep valued employees if it demonstrates that it is willing to invest in their professional development, by improving their skills and expertise through organizations support for their training on compliance of VAT via the internet (Gatigson \& Robertson, 2007).

\section{Tax Non-Compliance}

Tax non-compliance is defined as failure to comply with tax laws and/or report incorrect income, the act of claiming incorrect deductions, relief and rebates and/or paying the incorrect amount of tax beyond the stipulated 
time frame (Mohd et al, .2011). Tax non-compliance can takes place in the form of either tax Evasion and/or tax avoidance. Tax evasion is an attempt to escape tax liability (wholly or partially) by breaking the tax law and it is a criminal act since it is achieved principally by making false declarations such as under-reporting income or over-reporting relieves and allowances. Soyode and Kajola (2006), defined tax avoidance as the arrangement of tax payers affairs using tax shelters in the tax laws, and avoiding tax traps in the tax laws, so as to pay less tax than ought to be paid, hence the person pays less by taking the advantage of the loopholes in the tax laws.

\subsection{Empirical Review}

Bisrat (2010) The VAT is simply a multistage sales tax that exempts the purchase of intermediate goods and services from the tax base. This study, focusing on the Ethiopian case was analyzing the causes of noncompliance by VAT taxpayers. It was analyzed the impact of low audit probability, the perceived fairness of VAT, dissatisfaction with the tax authority, and how business people think about the VAT money on tax compliance. To gather adequate information for analysis purpose, a combination of quantitative and qualitative methods is applied. The final major factor studied was how business people think about the VAT money. These are taxpayers ${ }^{\text {ee }}$ beliefs on the relationship between VAT money and their business fund, the equivalence of VAT payment with the value added by the business, and taxpayers ${ }^{\text {ee }}$ contribution in the VAT collection. The findings of the study suggest these are not really a major problems concerning tax compliance.

Hailemariam (2011) studied on identifying and assessing the problems rose in association with the implementations of VAT by the Ethiopian Revenue and Customs Authority. The researcher used both qualitative and quantitative descriptive research designs and a sample of taxpayers and employees of the authority were selected using stratified random sampling method. The researcher used questionnaires, Interviews and relevant documents to collect primary and secondary data from the data sources. Pie charts, graphs, table, Percentages were used in analyzing the collected data. The study identified misunderstanding of the public in general and business community in particular regarding the VAT laws, resistance against registrations for VAT by some traders, administration inefficiency from ERCA, provisions of understated financial statements, and nonissuance of invoices or issuance of illegal invoices exercised by registered business enterprises was the main problems. The study recommends that the authority should train the taxpayers about the rules and regulations of VAT continuously, recruiting new employees and give nonstop training for the existing once, delegate the tax authority to regional and city administration and it should also increase its follow-up and investigation to control noncompliance enterprises, as well as effectively and efficiently performing the tasks of identification of VAT taxpayers, processing of returns, controlling collections, making refunds on time, auditing taxpayers, recognizing genuine taxpayers and levying penalties to tackle the problems it has encountered.

From the review of available literature, it is inferred that the topics undertaken in these limited research studies mainly focused on the drawbacks of sales tax and make justification for the introduction of VAT. Similarly, problems which could arise in introducing VAT have also been explored in some studies. There are only few studies which explore the effects of VAT after its introduction.

A study made by Wollela (2008) examines VAT administration in Ethiopia and identifies key problems including lack of sufficient number of skilled personnel and gaps in the administration in such areas as refunding, invoicing and filing requirements. The paper suggests that in Ethiopia attempting to implement what is legislated in the main areas (such as refunds) deserves the government's due attention. The study also emphasizes the need to strengthen the administration capacity in general and the tax audit program in particular. Besides the above researcher's knowledge, one can see that empirically studied research under taken by the above authors emphasis on how VAT system implemented and administered. However the researchers were motivated to investigate the status of VAT collection performance rather than its implementation and administration, particularly in West Shoa Zone. As far as the knowledge of researchers in West Shoa Zone, no researches have been investigated on determinants of Tax collection performance emphasis on Value Added Tax. Therefore, the current study believed to add value to this subject. 


\section{Conceptual framework}

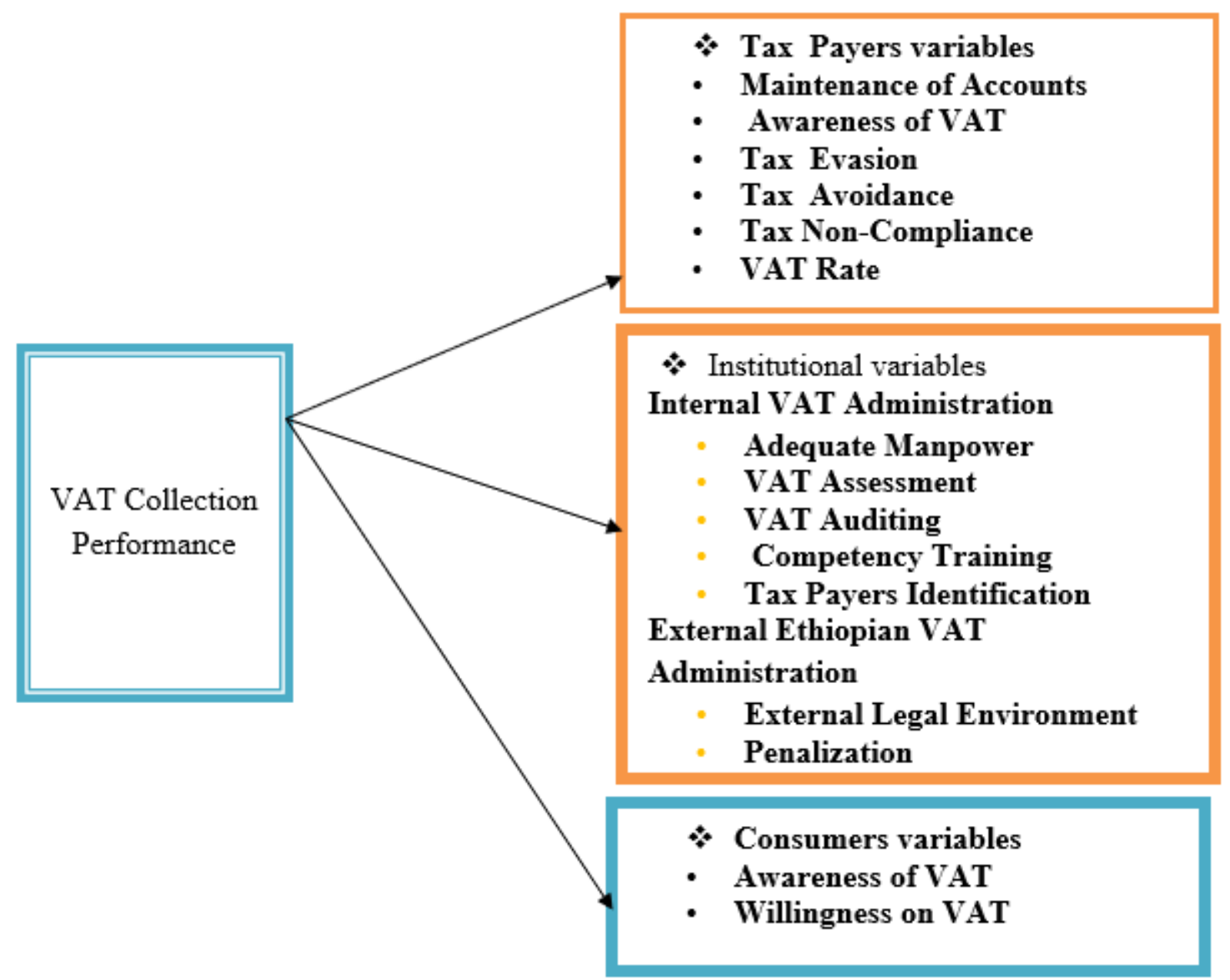

Source: Developed by researchers, 2018

\section{Material and Methods}

Both quantitative and Qualitative (mixed) research approach was used. Mixed research approaches helps to mitigate the bias in adopting only either qualitative or quantitative approach (Creswell, 2003). Both Primary and secondary data was used in the study. Primary data was obtained from different population based on their basic features of VAT registered tax payers, experts, Consumers and Revenues Authority administrations by using questionnaire from 391 respondents. Secondary data were collected from Annual reports of Oromia revenue Authority and West Shoa Zone Revenue authority. Finally, both descriptive and inferential statistics were used to analyze data. Descriptive statistics such as Pie charts, column chart, table, Percentages were used and inferential statistics used to diagnostic test. To see the relationships between the dependent and independent variables, multiple regressions were also used. In addition, collinearity tasted was taken to check interdependence and colllinearity among independent variables multiple regression and descriptive statistics were applied using procedures within SPSS version 20 and Classical linear Regression Model diagnostic Test were used Stata version 13.

\section{Model Specification}

Ordinary Least Square (OLS) model was used and constructed as follows:

$\mathbf{Y i}=\beta 0+\beta 1 X 1 i+\beta 2 X 2 i+\ldots+\beta k X k i+\varepsilon i(i ~ 1,2,3 \ldots, n)$

Where Yi is the ith observation of the dependent variable, X1i... Xki are the ith observation of the independent variables, $\beta 0 \ldots \beta \mathrm{k}$ are the regression coefficients, $\varepsilon i$ is the ith observation of the error term, and $\mathrm{n}$ is the number of observations.

Model 1

VCP $i=\alpha 0+\beta 1 T P A W O V i+\beta 2$ TPMOA $i+\beta 3 T E ~ i+\beta 4$ TA $i+\beta 5$ TNCOM $i+\beta 6$ VR $i+$ Ei..........................1 


\section{Model 2}

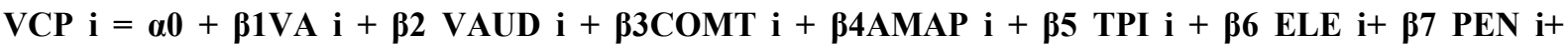
ci.....................2

Where: VCP $=$ Value added tax Collection Performance

$\beta 0=$ Constant Term

$\beta 1=$ Beta coefficients

TPAWOV=Tax payers awareness of VAT

TPMOA=Tax payers maintenance of accounts

VAUD $=$ VAT Auditing

$\mathrm{COMT}=$ Competence training

$\mathrm{TE}=$ Tax Evasion

$\mathrm{TA}=\mathrm{Tax}$ avoidance

TNCOM=Tax non-compliance

AMAP=Adequate Manpower

TPI=Tax payers identification

$\mathrm{VR}=\mathrm{VAT}$ Rate

ELE $=$ External legal environment

$\mathrm{VA}=\mathrm{VAT}$ Assessment

\section{Results and Discussions}

Questionnaire was distributed to 391 respondents whereas $353(90 \%)$ valid response was obtained and analyzed in this study. In the survey the back ground information of tax taxpayers were examined. The survey results are shown in the following:

Figures 4.1. Tax payers Registration year for VAT

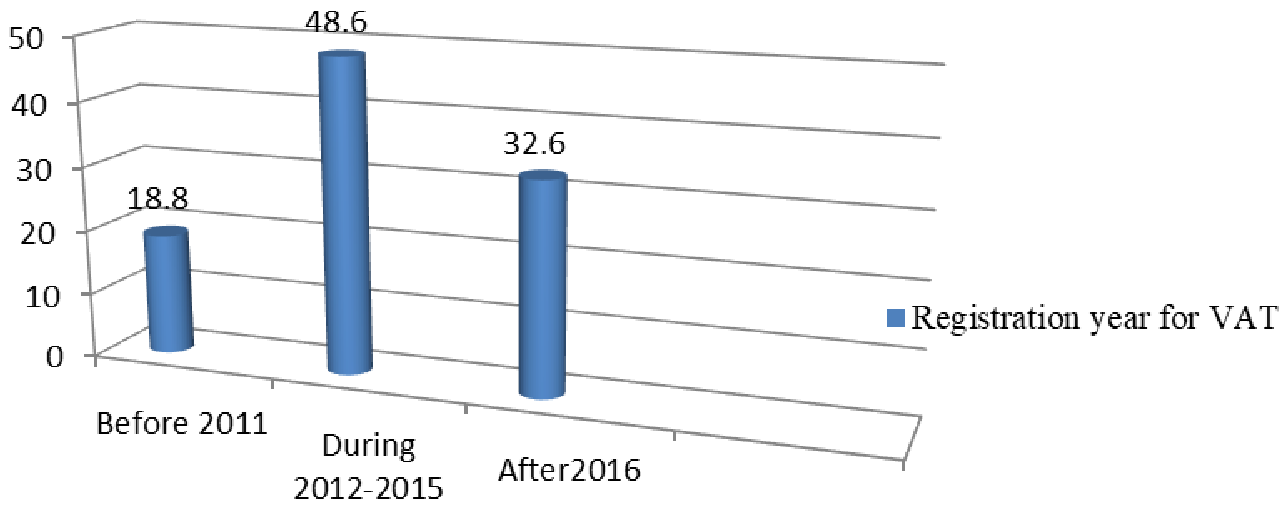

Source: Survey Result, 2018

As indicated in figure 4.1, the number of VAT registered tax payers increased from (42) $18.8 \%$ to (109)48.6\% during 2012-2015 years, but after year VAT registered tax payers declined which accounted (73) $32.6 \%$. This shows that Revenues Authority tax payer's identification becomes decline.

Figures 4.2.Areas of Trading

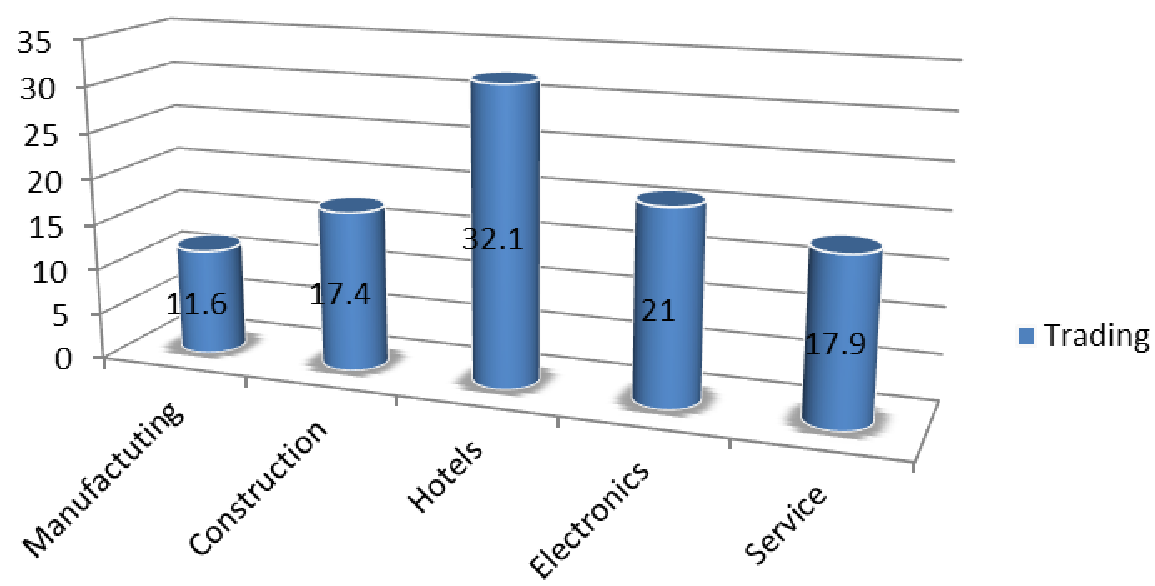

Source: Survey Result, 2018 
As shown in figure 4.2 in terms of area of occupation the share of West Shoa Zone VAT registered Tax payers for Hotel was $72(32.1 \%)$ accounted the highest percentage and Manufacturing 26(11.6\%) was the lowest percentage share of sector. It shows that majority of tax is come from the service nature of business.

\section{Figure 4.3.Avarage annual turnover of Tax payers}

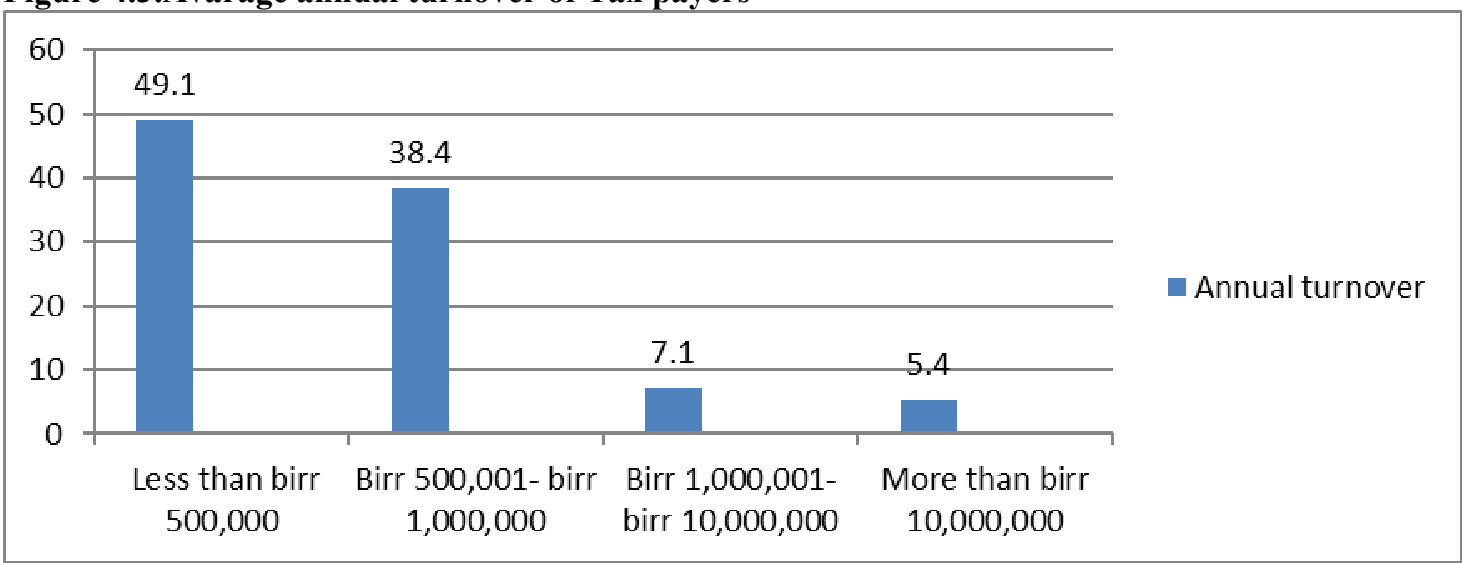

Source: Survey Result, 2018

As indicated in figure 4.3, the highest level of average annual turnover of West Shoa zone VAT registered taxpayers were less than 500,000 birr which accounted 110(49.1 and the lowest one was more than 10,000,000 birr that accounted only $12(5.4 \%)$.

Descriptive statics of VAT registered Tax Payers Variables Table 4.1.How did you know the concept of VAT

\begin{tabular}{|ll|r|r|r|r|}
\hline & Frequency & Percent & Valid Percent & Cumulative Percent \\
\hline \multirow{2}{*}{ Valid } & Radio & 57 & 25.4 & 25.4 & 25.4 \\
& By TV & 80 & 35.7 & 35.7 & 61.2 \\
& Pamphlets & 51 & 22.8 & 22.8 & 83.9 \\
& Training & 36 & 16.1 & 16.1 & 100.0 \\
& Total & 224 & 100.0 & 100.0 & \\
\hline
\end{tabular}

Source: Survey Result, 2018

Table 4.1.summarizes the source of information on the concept of VAT presented for Tax payers. Out of total respondents $80(35.7 \%)$ and $57(25.4 \%)$ VAT registered Tax payers got information from TV and radio respectively. $51(22.8 \%)$ and $36(16.1 \%)$ Tax payers got the concept of VAT from Pamphlets and training respectively. This indicated that most of VAT registered Tax payers were got concept VAT through television and radio programs respectively.

Table 4.2. Education and awareness creation program through media, broachers and others means is not sufficient to improve VAT compliance

\begin{tabular}{|ll|r|r|r|r|}
\hline & Frequency & Percent & Valid Percent & Cumulative Percent \\
\hline \multirow{2}{*}{ Valid } & 27 & 12.1 & 12.1 & 12.1 \\
& Strongly disagree & 32 & 14.3 & 14.3 & 26.3 \\
& Nisagree & 29 & 12.9 & 12.9 & 39.3 \\
& Agree & 95 & 42.4 & 42.4 & 81.7 \\
& strongly agree & 41 & 18.3 & 18.3 & 100.0 \\
Total & 224 & 100.0 & 100.0 & \\
\hline
\end{tabular}

Source: Survey Result, 2018

As we can see the above table, the respondents gave their opinion about whether West Shoa Zone gave enough awareness about VAT. Out of 224 respondents 50 or $(22.3 \%)$ of them said very low, 80 or $(35.7 \%)$ of them said low, 52 or $(23.2 \%)$ of them said satisfactory, 22 or $(9.8 \%)$ of them said good and $20(8.9 \%)$ of them said very well. This shows that West Shoa Zone Revenues Authority did not have enough training program to VAT registered Tax payers. 
Table 4.3. State your level of awareness of VAT procedure

\begin{tabular}{|l|r|r|r|r|}
\hline & Frequency & Percent & Valid Percent & Cumulative Percent \\
\hline Unaware & 12 & 5.4 & 5.4 & 5.4 \\
low aware of VAT procedure & 115 & 51.3 & 51.3 & 56.7 \\
Valid Moderately aware of VAT Procedure & 57 & 25.4 & 25.4 & 82.1 \\
completely aware of VAT & 40 & 17.9 & 17.9 & 100.0 \\
Total & 224 & 100.0 & 100.0 & \\
\hline
\end{tabular}

Source: Survey Result, 2018

Out 224 respondents 12 Tax payers (5.4\%) Responded that they do not have information regarding VAT and 115 Tax payers $(51.3 \%)$ low aware of VAT procedure while 57 Tax payers $(25.4 \%)$ have Moderately aware of VAT Procedure and 40 Tax payers $(17.9 \%)$ have completely aware of VAT procedure. It indicates according to the study most of Tax payers have insufficient information regarding VAT procedure.

\section{Table 4.4.Tax payers Maintenance of accounts}

\begin{tabular}{|c|c|c|c|c|c|}
\hline \multicolumn{6}{|c|}{ Descriptive statistics } \\
\hline Statement & 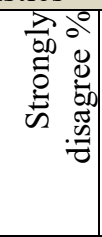 & 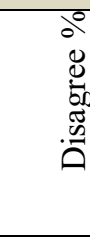 & $\frac{0}{0}$ & 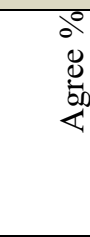 & 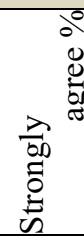 \\
\hline $\begin{array}{l}\text { Maintaining all Books of Accounts as per } \\
\text { required procedures \& guidelines of VAT } \\
\text { Proclamation is Cumbersome. }\end{array}$ & 17.9 & 4.5 & 8.5 & 37.8 & 31.3 \\
\hline $\begin{array}{l}\text { I am maintaining all Books of Accounts } \\
\text { of VAT as per proclamation. }\end{array}$ & 15.2 & 43.3 & 9.8 & 31.7 & 0.0 \\
\hline
\end{tabular}

Source: Survey Result, 2018

In terms of maintenance of accounts West Shoa Zone tax payers asked maintaining all Books of Accounts as per required procedures and guidelines of VAT Proclamation is cumbersome replay that (40)17.9\% strongly disagree, (10)4.5\% disagree, (85)37.8\% agree,(70)31.3\% strongly agree and (19) $8.5 \%$ neutral. Also the respondents asked whether they maintain all Books of Accounts of VAT as per proclamation. (34)15.2\% strongly disagree, (97)43.3\% disagree, (22)9.8\% neutral and (71)31.7\% agreed. This indicated that many of tax payers are not maintaining Book of account as per proclamation. Its observed that; most of the traders do not keep proper records of their transactions and those who keep proper records mostly default by keeping two different records to evade tax. Mostly they undervalue their turnover so that it does not qualify for VAT. Most small traders do not wish to register for VAT; because they will be forced to sale their products at a relatively higher price and so fail to compete effectively in the market. Therefore, the respondents say that, the West Shoa Zone Revenues Authority should employ effective methods in effective identification of the taxpayers as many of them do not wish to register voluntary.

Table 4.5.Tax Evasion

\begin{tabular}{|c|c|c|c|c|c|}
\hline \multicolumn{6}{|c|}{ Descriptive statistics } \\
\hline Statement & 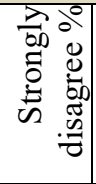 & 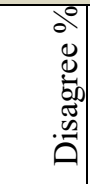 & $\frac{\partial}{\stackrel{\pi}{\pi}}$ & 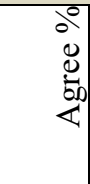 & 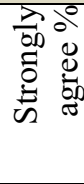 \\
\hline $\begin{array}{l}\text { In societies with a culture of high compliance with } \\
\text { VAT law, few VAT Registered Tax payers would } \\
\text { attempt tax evasion strategies. }\end{array}$ & 11.2 & 15.6 & 19.6 & 22.8 & 30.8 \\
\hline $\begin{array}{l}\text { Tax payers should evade VAT if the VAT system } \\
\text { is unfair. }\end{array}$ & 0.0 & 23.7 & 16 & 23.2 & 37.1 \\
\hline $\begin{array}{l}\text { Tax payers should evade VAT if many are doing } \\
\text { it. }\end{array}$ & 17.9 & 27.2 & 4.0 & 22.8 & 28.1 \\
\hline
\end{tabular}

Source: Survey Result, 2018

As it is indicated in table 4.5, the culture of tax compliance were observed, the result shows that few VAT Registered Tax payers would attempt tax evasion. Out of respondents (69)30.8\% strongly agree, (25) $11.2 \%$ strongly disagree and the other tax payers (35)15.6\% disagree, (51)22.8\% agree and (44)19.6\% neutral. This shows that, most of respondents strongly agreed in society with a culture of high compliance with VAT law but some VAT Registered Tax payers attempt tax evasion. For the Tax payers should evade VAT if the VAT system 
is unfair the respondents were respond (53)23.7\% disagreed, (52)23.2\% agreed, (83)37.1\% strongly agreed and (36)16\% neutral. On the other hand Tax payers asked, Tax payers evade VAT if many are doing it. They respond that (40)17.9\% strongly disagreed, (61)27.2\% disagreed, (9)4\% neutral, (51)22.8\% agreed and (63) $28.1 \%$ strongly agreed. The above table indicated that most of tax payers agreed on availability of tax evasion if the VAT system is unfair and if, many are doing it.

Table 4.6.Tax Avoidance

\begin{tabular}{|c|c|c|c|c|c|}
\hline \multicolumn{5}{|l|}{ Descriptive statistics } & \multirow[b]{2}{*}{ 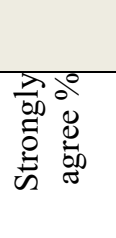 } \\
\hline Statement & 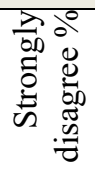 & 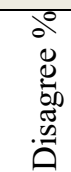 & 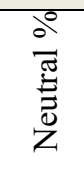 & 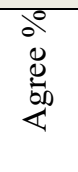 & \\
\hline $\begin{array}{l}\text { Tax payers legally reduce the VAT liabilities by } \\
\text { practices that take the full advantage of the tax } \\
\text { code, such as income splitting }\end{array}$ & 0 & 16.1 & 25 & 26.8 & 32.1 \\
\hline Splitting the business will affect the VAT. & 0 & 14.3 & 22.8 & 25 & 37.9 \\
\hline
\end{tabular}

Source: Survey Result, 2018

Table 4.6.indicated that Tax payers legally reduce the VAT liabilities by practices that take the full advantage of the tax code, such as income splitting (36)16.1\% disagreed, (56)25\% neutral and (60)26.8\% agreed, (72) $32.1 \%$ strongly agreed and for Splitting the business will affect the VAT the respondents respond that (32) $14.3 \%$ disagree, (51)22.8\% neutral, (56) $25 \%$ agreed and (85)37.9\% strongly agreed. This shows that most of Tax payers agreed the Splitting the business will affect the VAT.

Table 4.7.Tax Non-compliance

\begin{tabular}{|l|c|c|c|c|c|}
\hline \multicolumn{3}{|c|}{ Descriptive statistics } & \\
\hline Statement & \multicolumn{2}{|c|}{} & \\
\hline $\begin{array}{l}\text { There is Non-issuance of invoice to all buyers, this } \\
\text { result VAT non-compliance. }\end{array}$ & 0.0 & 0.0 & 0.0 & 53.6 & \\
\hline $\begin{array}{l}\text { The non-compliance of other taxpayers has a } \\
\text { negative impact on compliance tax payers'. }\end{array}$ & 0.0 & 0.0 & 3.6 & 29.9 & \\
\hline
\end{tabular}

Source: Survey Result, 2018

The respondents were asked there is Non-issuance of invoice to all buyers, the respondents respond that (120)53.6\%agreed, and (104)46.4\% strongly agreed. That implies that majority of tax payers agreed on Nonissuance of invoice. In addition the Tax payers asked the non-compliance of other taxpayers has a negative impact on compliance tax payers' (8)3.6\% neutral, (67) $29.9 \%$ agreed and (149) $66.5 \%$ strongly agreed. This means that most of Tax payers agreed on the non-compliance of other taxpayers has a negative impact on compliance tax payers.

Table 4.8.VAT Rate

\begin{tabular}{|c|c|c|c|c|c|}
\hline \multicolumn{5}{|c|}{ Descriptive statistics } & \multirow[b]{2}{*}{ 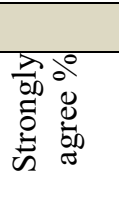 } \\
\hline Statement & 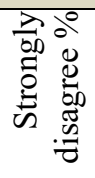 & 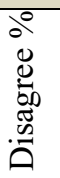 & $\begin{array}{l}\frac{0^{\circ}}{\pi} \\
\frac{\pi}{0} \\
\overline{0} \\
z\end{array}$ & $\begin{array}{l}0 \\
0 \\
0 \\
\stackrel{0}{0} \\
\dot{\alpha}\end{array}$ & \\
\hline $\begin{array}{l}15 \% \text { single VAT rate on all items of goods and } \\
\text { services. In my opinion single VAT rate is unfair. }\end{array}$ & 13.8 & 18 & 16.5 & 32.1 & 19.6 \\
\hline $\begin{array}{l}\text { If the level of VAT rate is high the income of VAT } \\
\text { will be high. }\end{array}$ & 0.0 & 8.5 & 6.7 & 33.5 & 51.3 \\
\hline
\end{tabular}

Source: Survey Result, 2018

Table 4.8. Shows that the questions were asked Whether a single tax rate is fair or not. (31)13.8\% Strongly disagreed, (40)18\% disagreed, (37)16.5\% neutral, (72)32.1\% agreed and (44)19.6\% agreed .While (19)8.5\% disagreed, (15)6.7\% neutral, (75)33.5\% agreed and (115)51.3\% strongly agreed, if the level of VAT rate is high the income of VAT will be high. It indicated that single VAT rate on all items of goods and services are not fair 
and agreed on the level of high VAT rate increase VAT income.

Table 4.9. Awareness Mechanisms/Procedures for raising objection against penalty

\begin{tabular}{|ll|r|r|r|r|}
\hline & Frequency & Percent & Valid Percent & Cumulative Percent \\
\hline \multirow{4}{*}{ Valid } & Disagree & 45 & 20.1 & 20.1 & 20.1 \\
& Agree & 57 & 25.4 & 25.4 & 45.5 \\
& Strongly agree & 122 & 54.5 & 54.5 & 100.0 \\
& Total & 224 & 100.0 & 100.0 & \\
\hline
\end{tabular}

Source: Survey Result ,2018

Respondents were asked questions related to Awareness on Mechanisms for raising objection against penalty is low. They respond that $45(20.1 \%)$ disagreed, 57(25.4\%) agreed and 122(54.5\%) strongly agreed. It implies that the majority of respondents have insufficient awareness on Mechanisms/procedures for raising objection against penalty.

Table 4.10. Have you ever penalized by the Revenues Authority

\begin{tabular}{|c|c|c|c|c|c|}
\hline & & Frequency & Percent & Valid Percent & $\begin{array}{c}\text { Cumulative } \\
\text { Percent }\end{array}$ \\
\hline \multirow{4}{*}{ Valid } & Late payment & 39 & 17.4 & 17.4 & 17.4 \\
\hline & Non-issuance of VAT invoice & 10 & 4.5 & 4.5 & 21.9 \\
\hline & Not at all & 175 & 78.1 & 78.1 & 100.0 \\
\hline & Total & 224 & 100.0 & 100.0 & \\
\hline
\end{tabular}

Source: Survey Result, 2018

Findings further revealed that respondents who have been penalized by West Shoa Revenues Authority because of late payment were $39(17.4 \%)$ and $10(4.5 \%)$ of the respondents have been penalized due to Nonissuance of VAT invoice whereas a majority of respondents $175(78.1 \%)$ have never been penalized.

\section{Descriptive statistics of VAT Revenues Authority employees Variables}

Data was also collected from employees of Revenue office and result obtained from them was summarized as follows:

Internal VAT administration

Table4.11. Adequate Manpower

\begin{tabular}{|c|c|c|c|c|c|}
\hline \multicolumn{6}{|c|}{ Descriptive statistics } \\
\hline Statement & 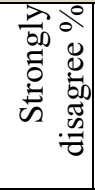 & 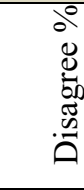 & 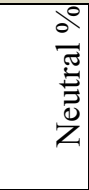 & 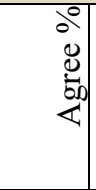 & 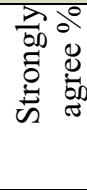 \\
\hline $\begin{array}{l}\text { In conducting Revenue Collection, the Revenues } \\
\text { Authority has sufficient Staff Members. }\end{array}$ & 23.0 & 63.5 & 0.00 & 13.5 & 0.0 \\
\hline $\begin{array}{l}\text { There is shortage of resources and infrastructural } \\
\text { facilities to implement and enhance the enforcement } \\
\text { of VAT Law. }\end{array}$ & 12.2 & 6.8 & 0.00 & 43.2 & 37.8 \\
\hline
\end{tabular}

Source: Survey Result, 2018

The respondents were asked in conducting Revenue Collection, the Revenues Authority has sufficient Staff Members. (47)63.5\% of the respondents disagreed, (17)23\% of the respondents strongly disagreed, and (10) $13.5 \%$ of the respondent's agreed. It revealed that the Revenues Authority did not have sufficient Staff Members. On the other hand there is shortage of resources and infrastructural facilities to implement and enhance the enforcement of VAT Law, (28)37.8\% strongly agreed (32)43.2\% agree and (5)6.8\% disagreed and (9) $12.2 \%$ strongly disagree. This shows that most of the respondents agreed on there are shortage of resources and infrastructural facilities to implement and enhance the enforcement of VAT Law. 
Table4.12. VAT Assessment

\begin{tabular}{|c|c|c|c|c|c|}
\hline \multicolumn{6}{|c|}{ Descriptive statistics } \\
\hline Statement & 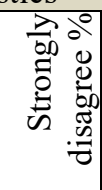 & 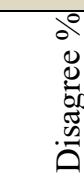 & $\begin{array}{l}\frac{0}{0} \\
\frac{\pi}{ \pm} \\
\overline{0} \\
\overline{0} \\
Z\end{array}$ & $\begin{array}{l}0 \\
0 \\
0 \\
0 \\
0 \\
\overline{4} \\
\end{array}$ & 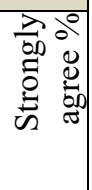 \\
\hline $\begin{array}{l}\text { There is intense follow up and supervision over } \\
\text { the identified VAT payers. }\end{array}$ & 14.9 & 55.4 & 5.4 & 13.5 & 10.8 \\
\hline Tax payers' VAT report assessed on time. & 27.0 & 39.2 & 6.8 & 0.0 & 27.0 \\
\hline $\begin{array}{l}\text { VAT registered Tax payers have trust in } \\
\text { assessment, and collection procedures }\end{array}$ & 6.8 & 59.4 & 12.2 & 21.6 & 0.0 \\
\hline
\end{tabular}

Source: Survey Result, 2018

Respondents were asked on whether there is intense follow up and supervision over the identified VAT payers. The following were the responses; (41)55.4\% of the respondents disagreed, (10)13.5\% agreed while (8) $10.8 \%$ strongly agreed, (11)14.9\% strongly disagreed and (4)5.4\% remained neutral. It indicated that less close follow up and supervision by West Shoa Zone Revenues Authority on identified taxpayers. On the Tax payers' VAT report assessed on time, (20) 27\% strongly disagreed, (29)39.2\% disagreed, (5)6.8\% neutral, and (20) $27 \%$ strongly agreed. It implies majority of respondents disagreed on Tax payers' VAT report assessed on time. For the question VAT registered Tax payers have trust in assessment and collection procedures. (44)59.4\% disagreed, (5)6.8\% strongly disagreed, (9)12.2\% neutral and (16)21.6\% agreed. It shows that most of VAT registered Tax payers have not trust in assessment, and collection procedure.

\section{Table 4.13.VAT Auditing}

\begin{tabular}{|c|c|c|c|c|c|}
\hline \multicolumn{6}{|c|}{ Descriptive statistics } \\
\hline Statements & 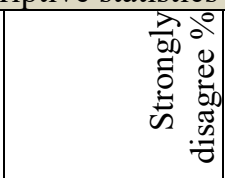 & 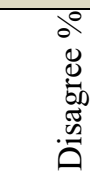 & $\frac{20}{\overparen{\pi}}$ & 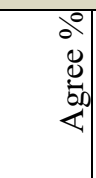 & 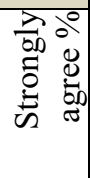 \\
\hline $\begin{array}{l}\text { Procedures of } \text { VAT Audit are } \\
\text { Cumbersome. }\end{array}$ & 10.8 & 16.2 & 13.5 & 25.7 & 33.8 \\
\hline $\begin{array}{l}\text { In conducting continuous audit, the number } \\
\text { of audit staff is sufficient for detecting VAT } \\
\text { avoided taxpayers. }\end{array}$ & 39.2 & 60.8 & 0.0 & 0.0 & 0.0 \\
\hline Tax payers VAT report Audited on time. & 43.2 & 39.2 & 0.00 & 17.6 & 0.00 \\
\hline
\end{tabular}

Source: Survey Result, 2018

Respondents were asked whether Procedures of VAT Audit are Cumbersome. (8)10.8 \% strongly agreed, (12)16.2 \% disagree, (10)13.5\% neutral, (19)25.7\% agreed and (25)33.8 \% strongly agreed. According to many respondents reviled that the Procedures of VAT Audit are Cumbersome and for the question in conducting continuous audit, the number of audit staff is sufficient for detecting VAT avoided tax payers, (45)60.8\% disagreed and (29)39.2\% strongly disagree. This implies that number of audit staff was not sufficient for detecting VAT avoided taxpayers. For question tax payers VAT report Audited on time. (32)43.2\% strongly disagreed, (29)39.2\% disagreed agreed and (13)17.6\% agreed. This result suggested that majority of tax payers have never been audited by the tax authority for tax audit because of lack of auditor.

Table4.14. Competency Training

\begin{tabular}{|c|c|c|c|c|c|}
\hline \multicolumn{6}{|c|}{ Descriptive statistics } \\
\hline Statements & 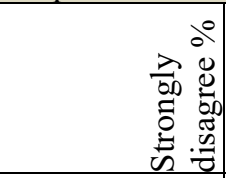 & 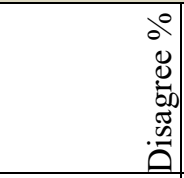 & 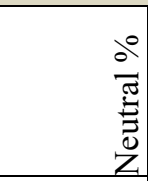 & $\begin{array}{l}0 \\
0 \\
0 \\
0 \\
0 \\
\end{array}$ & 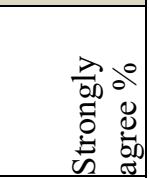 \\
\hline $\begin{array}{l}\text { Revenue Authority offered adequate } \\
\text { training about VAT. }\end{array}$ & 20.3 & 48.6 & 2.7 & 20.3 & 8.1 \\
\hline $\begin{array}{l}\text { Training provided to employees at } \\
\text { different levels of the staff is sufficient } \\
\text { in promoting the capacity of employees. }\end{array}$ & 18.9 & 52.7 & 4.1 & 10.8 & 13.5 \\
\hline
\end{tabular}

Source: Survey Result, 2018

Table4.14. shows that the respondents were asked Revenue Authority offered adequate training about VAT. (15)20.3\% strongly agreed, (36)48.6\% disagreed, (2)2.7\% neutral, (15)20.3\% agreed and (6) $8.1 \%$ strongly 
agreed. It indicated the Revenue Authority did not offer adequate training about VAT. On the question Training provided to employees at different levels of the staff is sufficient in promoting the capacity of employees. (14)18.9\% strongly disagreed, (39)52.7\% disagreed, (3)4.1\% neutral, (8)10.8\% agreed and (10)13.5 \% strongly agreed. It implies that adequate Training was not provided to most of employees at different levels of the staff in promoting the capacity of employees.

Table4.15. Tax payer's identification

\begin{tabular}{|c|c|c|c|c|c|}
\hline \multicolumn{6}{|c|}{ Descriptive statistics } \\
\hline Statements & 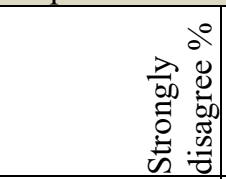 & 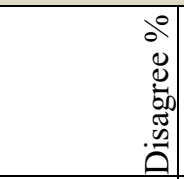 & $\frac{\partial}{\pi}$ & 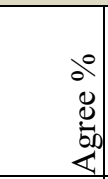 & 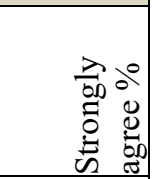 \\
\hline $\begin{array}{l}\text { There are tax payers yet to be registered } \\
\text { for VAT but Revenue Authority so far } \\
\text { not included. }\end{array}$ & 5.3 & 9.5 & 0.0 & 28.4 & 56.8 \\
\hline $\begin{array}{l}\text { The methods used by West Shoa Zone } \\
\text { Revenues Authority to identify tax } \\
\text { payers are adequate. }\end{array}$ & 13.5 & 64.9 & 0.0 & 21.6 & 0.0 \\
\hline
\end{tabular}

Source: Survey Result, 2018

Respondents were asked there are tax payers yet to be registered for VAT but Revenues Authority so far not included. The following were the responses; (42)56.8\% of the respondents strongly agreed, (21)28.4\% agreed while (7)9.5\% disagreed, and (4)5.3\% of the respondents were strongly disagreed on the tax payer's identification. It implies that there were tax payers yet to be registered for VAT but Revenue Authority so far not included. Also the respondents were asked the methods used by West Shoa Zone Revenues Authority to identify tax payers are adequate. They respond that $13.5 \%$ strongly disagreed, $64.9 \%$ disagreed and $21.6 \%$ agreed. This indicated that the methods used by West Showa Zone Revenues Authority to identify tax payers are not adequate.

External Ethiopian VAT administration Table 4.16.External Legal environment

\begin{tabular}{|c|c|c|c|c|c|}
\hline \multicolumn{6}{|l|}{ Descriptive statistics } \\
\hline Statements & 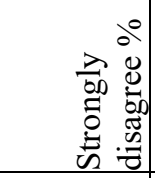 & 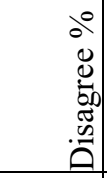 & 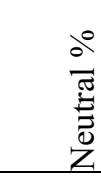 & 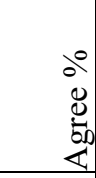 & 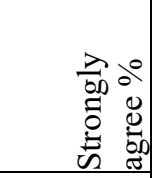 \\
\hline $\begin{array}{l}\text { Tax payers who need to register for VAT when their } \\
\text { annual turnover was more than Birr } 1 \text { million. The } \\
\text { Required turnover of Birr } 1 \text { Million is very high } \\
\text { standard. }\end{array}$ & 0.0 & 12.2 & 0.0 & 23.0 & 64.8 \\
\hline $\begin{array}{l}\text { It should be worthwhile to amend the possibility of } \\
\text { reducing the requirement of } 1 \text { Million Turnover. }\end{array}$ & 2 & 13 & 0.0 & 51.4 & 33.6 \\
\hline
\end{tabular}

Source: Survey Results, 2018

Respondents were asked that Tax payers who need to register for VAT when their annual turnover was more than Birr1 million. The Required turnover of Birr 1 Million is very high standard. (48) $64.8 \%$ of the respondents strongly agreed, (17)23\% agreed while (9)12.2\% disagreed on the registration threshold being high. In addition the respondents were asked it should be worthwhile to amend the possibility of reducing the requirement of 1 Million Turnover. (2)2\% strongly disagreed, (9)13\% disagreed (38)51.4\% agreed and (25)33.6\% strongly agreed. Some of the respondents argued that this amount is higher and suggest that it should be lowered. They say that, small businesses wishing to secured businesses with registered businesses are unable because they are not registered and would wish to but the constrain remains to be the registration threshold. Some of the respondents say that, the nature of the businesses they are in requires them to register for VAT and be able to even get tenders but they are not in the position because they are not registered. Most respondents suggest that, the registration threshold should be reviewed to a position of being able to accommodate many businesses despite the fact that it will demand more administration for it to work effectively. 
Table 4.17.Penalization

\begin{tabular}{|c|c|c|c|c|c|}
\hline \multicolumn{6}{|c|}{ Descriptive statistics } \\
\hline Statements & 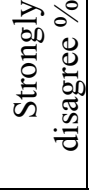 & 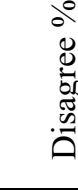 & $\frac{00}{\pi}$ & 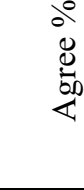 & 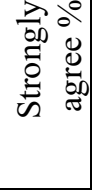 \\
\hline $\begin{array}{l}\text { There is lack of commitment in VAT experts to } \\
\text { impose penalty on tax payers as per } \\
\text { proclamation. }\end{array}$ & 6.8 & 14.9 & 2.6 & 41.9 & 33.8 \\
\hline $\begin{array}{l}\text { There is lack of transparency and consistency in } \\
\text { imposing penalties. }\end{array}$ & 2.7 & 20.3 & 0.0 & 54 & 23.0 \\
\hline $\begin{array}{l}\text { If there is no penalty or legal enforcement, there } \\
\text { is a possibility that VAT registered Tax payers } \\
\text { may not pay VAT. }\end{array}$ & 0.0 & 8.1 & 2.7 & 16.2 & 73.0 \\
\hline
\end{tabular}

Source: Survey Result, 2018

Table 4.17. shows that the respondents are asked there is lack of commitment in VAT experts to impose penalty on tax payers as per proclamation. The respondents respond that (5)6.8\% strongly disagreed, (11) $14.9 \%$ disagreed, (2)2.6\% neutral, (31)41.9\% agreed and (25)33.8\% strongly agreed. For the question there is lack of transparency and consistency in imposing penalties, (2)2.7\% strongly disagreed, (15)20.3\% disagreed, (40)54\% agreed and (17)23\% strongly agreed. Whereas for if there is no penalty or legal enforcement, there is a possibility that VAT registered Tax payers may not pay VAT they respond that (6)8.1\% disagreed, (2) $2.7 \%$ neutral, (12)16.2\% agreed and (54)73\% strongly agreed. It indicates that majority of respondents argued that there is lack of commitment in VAT experts to impose penalty on tax payers as per proclamation, lack of transparency and consistency in imposing penalties and if there is no penalty or legal enforcement, there is a possibility that VAT registered Tax payers may not pay VAT.

Table 4.18.Tax payer's penalty for Non-issuance of invoice, Non-post advertisement and Obstruction of Administration

\begin{tabular}{|l|l|l|l|l|l|l|}
\hline & \multicolumn{2}{|l|}{$\begin{array}{l}\text { Ambo City } \\
\text { Administration Revenues } \\
\text { Authority }\end{array}$} & $\begin{array}{l}\text { Dandi Woreda Revenues } \\
\text { Authority }\end{array}$ & \multicolumn{2}{c|}{$\begin{array}{r}\text { Bako Woreda Revenues } \\
\text { Authority }\end{array}$} \\
\cline { 2 - 7 } Description & Frequency & Percent & Frequency & Percent & Frequency & Percent \\
\hline $\begin{array}{l}\text { Non-issuance of } \\
\text { invoice }\end{array}$ & 7 & 1.21 & 3 & 3.9 & - & - \\
\hline $\begin{array}{l}\text { Non-post } \\
\text { advertisement }\end{array}$ & 4 & 0.69 & - & - & - & - \\
\hline $\begin{array}{l}\text { Obstruction of } \\
\text { Administration }\end{array}$ & 2 & 0.35 & - & - & - & - \\
\hline Total & 13 & 2.25 & 3 & 3.9 & - & - \\
\hline
\end{tabular}

Source: West Showa Revenues Authority, 2018

The above table shows that out of 578 VAT registered Tax payers in Ambo city administration Revenues Authorities $13(2.55 \%)$ were penalized. That means $7(1.21 \%)$ by Non-issuance of invoice, $4(0.695)$ by Non-post advertisement and 2(0.35) by Obstruction to Revenues. In case of Dandi Woreda Revenues Authority out of 77 VAT registered Tax payers only 3(3.9\%) were penalized by Non-issuance of invoice but in Bako Woreda Revenues Authority, out of 80 VAT registered Tax payers none of them were not penalized in 2017 year. In general it reviled that in West Shoa zone Revenues Authority there is poor practice on imposing penalty on VAT registered Tax payers. 
VAT collection Performances

Table4.19. VAT collection Performances

\begin{tabular}{|l|l|l|l|l|l|}
\hline \multicolumn{7}{|c|}{ From VAT Registered Tax payers } & & \\
\hline & & & & \\
\hline Statements & & & & & \\
\hline $\begin{array}{l}\text { The percentage change of total revenue collections } \\
\text { from VAT is increasing from year to year, but not } \\
\text { meets the targets. }\end{array}$ & 4.0 & 12.1 & 6.7 & 43.3 & 33.9 \\
\hline $\begin{array}{l}\text { Revenue Authority witnessed unachieved VAT } \\
\text { Targets. }\end{array}$ & 0.0 & 7.6 & 13.8 & 45.5 & 33.1 \\
\hline $\begin{array}{l}\text { In West Shoa Zone Revenues Authority the VAT } \\
\text { income is affected due to lack of intensive follow up. }\end{array}$ & 0.0 & 3.1 & 8.1 & 52.2 & 36.6 \\
\hline From Revenues Authority Employee's & & & & & \\
\hline $\begin{array}{l}\text { The percentage change of total revenues collection } \\
\text { from VAT is increasing from year to year, but not } \\
\text { meets the targets. }\end{array}$ & 0.0 & 0.0 & 0.0 & 74.3 & 25.7 \\
\hline $\begin{array}{l}\text { Revenue Authority witnessed unachieved VAT } \\
\text { Targets. }\end{array}$ & 0.0 & 0.0 & 6.8 & 54 & 39.2 \\
\hline $\begin{array}{l}\text { In West Showa Zone Revenues Authority the VAT } \\
\text { income is affected due to lack of intensive follow up. }\end{array}$ & 0.0 & 13.5 & 10.8 & 56.8 & 18.9 \\
\hline
\end{tabular}

Source: Survey Result, 2018

VAT registered Tax payers Respondents were asked to give their views on the percentage change of total revenue collections from VAT is increasing from year to year, but not the meet the targets. $33.9 \%$ of the respondents strongly agreed, $43.3 \%$ agreed, $6.7 \%$ remained neutral while $12.1 \%$ disagreed and $4 \%$ strongly disagreed. In addition to that the Respondents were asked Revenue Authority witnessed unachieved VAT Targets, $33.1 \%$ of respondents strongly agreed, $45.5 \%$ agreed, $13.8 \%$ neutral and $7.6 \%$ disagreed on unachieved VAT Targets. Also the respondents asked VAT income is affected due to lack of intensive follow up, 36.6\% strongly agreed, $52.2 \%$ agreed, $8.1 \%$ neutral and $3.1 \%$ disagreed. This indicates that the percentage change of total VAT collections from year to year is not meets the target.

Whereas the question for Revenues Authority employees asked the percentage change of total revenue collections from VAT is increasing from year to year, but not the meet the targets, $74.3 \%$ agreed and $25.7 \%$ strongly agreed. For the question Revenue Authority witnessed unachieved VAT Targets, 39.2\% strongly agreed, 54\% agreed and 6.8\% neutral and finally the Revenues Authority employees were asked VAT income is affected due to lack of intensive follow up, $18.9 \%$ strongly agreed, and $56.8 \%$ agreed, $10.8 \%$ neutral and $13.5 \%$ disagreed. this indicates that even if the revenue collections from VAT is increasing from year to year, but not the meet the targets due to lack of intensive follow up.

Moreover data was collected from Consumers and result was summarized as follows:

Question about Consumers Awareness of VAT and willingness to pay VAT

Table 4.20.State your level of awareness on VAT

\begin{tabular}{|ll|r|r|r|r|}
\hline & Frequency & Percent & Valid Percent & Cumulative Percent \\
\hline \multirow{2}{*}{ Valid } & 15 & 30.0 & 30.0 & 30.0 \\
Little aware & 28 & 56.0 & 56.0 & 86.0 \\
Moderately aware & 5 & 10.0 & 10.0 & 96.0 \\
completely aware & 2 & 4.0 & 4.0 & 100.0 \\
Total & 50 & 100.0 & 100.0 & \\
\hline
\end{tabular}

Source: Survey Result, 2018

The above table shows that the respondents were asked to State level of awareness on VAT. They replied that $28(56 \%)$ have little aware, $15(30 \%)$ unaware, 5(10\%) moderately aware and 2(4\%) completely aware. Therefore majority of consumers respondents of the study have little aware of VAT. 
Table4.21. As per VAT proclamation, all VAT registered tax payers give invoice to consumers, but they are not practicing so

\begin{tabular}{|ll|r|r|r|r|}
\hline & Frequency & Percent & Valid Percent & Cumulative Percent \\
\hline \multirow{2}{*}{ Disagree } & 5 & 10.0 & 10.0 & 10.0 \\
Neutral & 8 & 16.0 & 16.0 & 26.0 \\
& Agree & 21 & 42.0 & 42.0 & 68.0 \\
strongly agree & 16 & 32.0 & 32.0 & 100.0 \\
Total & 50 & 100.0 & 100.0 & \\
\hline
\end{tabular}

Source: Survey Result, 2018

The respondents were asked as per VAT proclamation, all VAT registered tax payers should give invoice to consumers, but they are not practicing so. From the fifty respondents $21(42 \%)$ agreed, 16(32\%) strongly agree, $5(10 \%)$ disagreed and $8(16 \%)$ neutral. It indicated that most consumers respondents were agreed to as per VAT proclamation, all VAT registered tax payers give invoice to consumers, but they are not practicing.

Table4.22. Do you ask receipt after you pay

\begin{tabular}{|ll|r|r|r|r|}
\hline & Frequency & Percent & Valid Percent & Cumulative Percent \\
\hline \multirow{2}{*}{ Valid } & No & 15 & 30.0 & 30.0 & 30.0 \\
& Some times & 30 & 60.0 & 60.0 & 90.0 \\
& Always & 5 & 10.0 & 10.0 & 100.0 \\
& Total & 50 & 100.0 & 100.0 & \\
\hline
\end{tabular}

Source: Survey Result, 2018

Table 4.22.indicated that the respondents were asked do you ask receipt after you pay. They respond that 30 $(60 \%)$ some times, $15(30 \%)$ no and $5(10 \%)$ always ask receipt after pay. This shows that majority of consumers were asked receipt Sometimes after pay.

Table4.23. Do you check the receipt whether it is legal or not

\begin{tabular}{|ll|r|r|r|r|}
\hline & Frequency & Percent & Valid Percent & Cumulative Percent \\
\hline \multirow{4}{*}{ Valid } & No & 31 & 62.0 & 62.0 & 62.0 \\
& Sometimes & 19 & 38.0 & 38.0 & 100.0 \\
& Total & 50 & 100.0 & 100.0 & \\
\hline
\end{tabular}

Source: Survey Result, 2018

On the above table the consumers respondents were asked to check the receipt whether it is legal or not. The respondent's replies that $31(62 \%)$ no whereas $19(38 \%)$ were sometimes. The result indicated that the majority of respondents do not check the receipt whether it is legal or not.

Table4.24. Consumers are not willing to buy goods and services with VAT

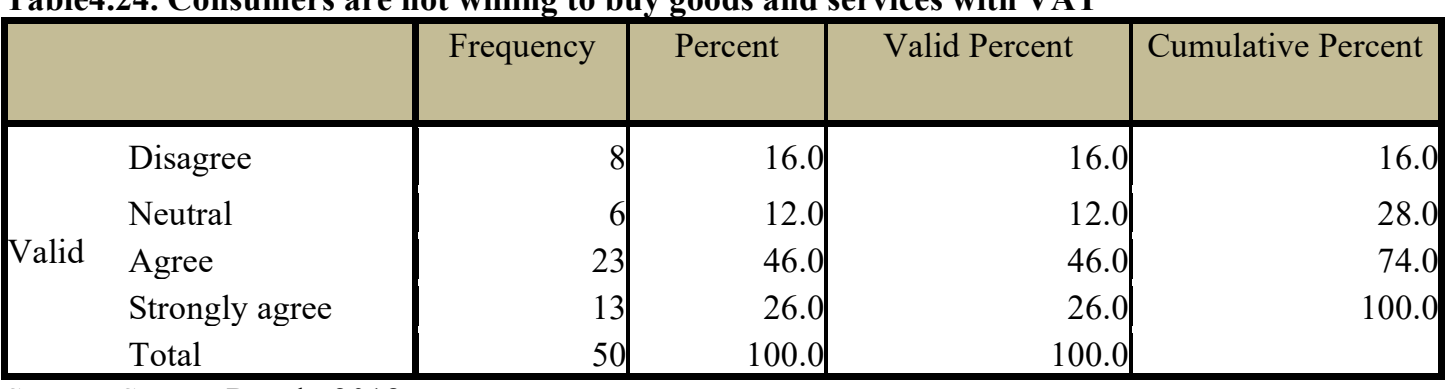

Source: Survey Result, 2018

As it's shown from the above Table 4.27.consumers respondents were asked to express their view about Consumers are not willing to buy goods and services with VAT. Consequently, 23(46\%) of consumers were replied that agreed, $13(26 \%)$ of consumers were responded strongly agreed, $8(16 \%)$ of consumers were answered disagreed and $6(12 \%)$ of consumers were replied that neutral. Therefore, from this finding, the majority of the respondents of Consumers were not willing to buy goods and services with VAT. It can conclude that the main reason for not willing to buy goods and services with VAT, by most consumers were lack of awareness about VAT.

Status of VAT income as a percentage of total tax revenue

For analysis purpose, VAT collection with its respective total tax revenue collection 2011 to 2017 year for West Shoa Zone Revenues Authority showed in the following: 
Table 4.25. Status of VAT income to tax revenue ratio of West Shoa Zone Revenues Authority2011-2017

\begin{tabular}{|c|c|c|c|c|c|c|c|}
\hline \multicolumn{8}{|c|}{ Years } \\
\hline Items & 2011 & 2012 & 2013 & 2014 & 2015 & 2016 & 2017 \\
\hline $\begin{array}{l}\text { VAT revenue for } \\
\text { Oromia Revenues } \\
\text { Authority }\end{array}$ & $\begin{array}{l}352,336, \\
347.78\end{array}$ & $\begin{array}{l}596,418, \\
309.95\end{array}$ & $\begin{array}{l}1,064,724, \\
165.26\end{array}$ & $\begin{array}{l}1,591,103, \\
555.94\end{array}$ & $\begin{array}{l}1,876,016, \\
320.27\end{array}$ & $\begin{array}{l}1,854,478, \\
576.90\end{array}$ & $\begin{array}{l}1,734,023, \\
976.37\end{array}$ \\
\hline $\begin{array}{l}\text { Tax revenue for } \\
\text { Oromia Revenues } \\
\text { Authority }\end{array}$ & $\begin{array}{l}2,338,853, \\
918.20\end{array}$ & $\begin{array}{l}3,591,265, \\
892.02\end{array}$ & $\begin{array}{l}4,961,966, \\
134.92\end{array}$ & $\begin{array}{l}7,132,123, \\
567.18\end{array}$ & $\begin{array}{l}9,164,187, \\
212.15\end{array}$ & $\begin{array}{l}10,445,114, \\
340.72\end{array}$ & $\begin{array}{l}10,595,572, \\
949.96\end{array}$ \\
\hline $\begin{array}{l}\text { Percentage of VAT } \\
\text { revenue to tax } \\
\text { revenue } \\
\text { for Oromia } \\
\text { Revenues } \\
\text { Authority }\end{array}$ & $15.06 \%$ & $16.61 \%$ & $21.46 \%$ & $22.31 \%$ & $20.47 \%$ & $17.75 \%$ & $16.37 \%$ \\
\hline $\begin{array}{l}\text { VAT revenue for } \\
\text { West Shoa Zone } \\
\text { Revenues } \\
\text { Authority }\end{array}$ & $\begin{array}{l}3,421, \\
294.44\end{array}$ & $\begin{array}{l}\text { 11,927, } \\
719.12\end{array}$ & $\begin{array}{l}25,476 \\
438.88\end{array}$ & $\begin{array}{l}21,727 \\
602.55\end{array}$ & $\begin{array}{l}23,795, \\
227.41\end{array}$ & $\begin{array}{l}27,417, \\
387.4\end{array}$ & $\begin{array}{l}29,212 \\
623.92\end{array}$ \\
\hline $\begin{array}{l}\text { Tax revenue for } \\
\text { West Shoa Zone } \\
\text { Revenues } \\
\text { Authority }\end{array}$ & $\begin{array}{l}103,553, \\
436.22\end{array}$ & $\begin{array}{l}168,023, \\
764.00\end{array}$ & $\begin{array}{l}194,073, \\
430.69\end{array}$ & $\begin{array}{l}228,351, \\
244.68\end{array}$ & $\begin{array}{l}321,431, \\
351.33\end{array}$ & $\begin{array}{l}351,431, \\
084.05\end{array}$ & $\begin{array}{l}366,604, \\
991.97\end{array}$ \\
\hline $\begin{array}{l}\text { Percentage of VAT } \\
\text { revenue to tax } \\
\text { revenue } \\
\text { for West Shoa } \\
\text { Zone Revenues } \\
\text { Authority }\end{array}$ & $3.31 \%$ & $7.1 \%$ & $13.13 \%$ & $9.51 \%$ & $7.4 \%$ & $7.8 \%$ & $7.96 \%$ \\
\hline
\end{tabular}

Source: Oromia Revenues Authority and West Shoa Zone Revenues Authority 2011-2017

The table 4.25 shown that the share of VAT in Oromia Revenues Authority in total tax revenue ranges from $15.06 \%$ in the year 2011 to $22.31 \%$ in year 2014 . Indeed, the average for the seven years was $18.60 \%$. However, during the years 2011, 2012, 2016 and 2017 the share of VAT to tax revenue was lower than the average value of the seven years. In short the share of VAT to tax revenue was highest in the year 2014 and lowest in the year 2011. Moreover, the share of VAT in total tax revenue for West Shoa Zone Revenues Authority ranges $3.31 \%$ in the year 2011 to $13.13 \%$ in 2013 .

\section{Regression Analysis}

Regression analysis was conducted to empirically determine whether independent variables were significant with dependent variables. The regression analysis was done with VAT collection performance as dependent variable and determinants of VAT collection performance as independent variables (Tax payer's awareness of VAT, Tax payer's maintenance of account, Tax Evasion, Tax Avoidance, Tax Non-compliance, and VAT Rate) Tax payers point of view and VAT assessment, VAT audit, Competence training, Adequate manpower, Tax payers identification, External legal Environment and penalization on institutional point of view.

\section{Model summery of Tax payers related variables}

The regression results in the table4.30.indicated the goodness of fit for the regression between independent variables and dependent variables was satisfactory in the multiple regressions. An R squared of 0.63 indicates that $63 \%$ of the relationship explained by the identified six factors namely Tax payer's awareness of VAT, Tax payer's maintenance of account, Tax Evasion, Tax Avoidance, Tax Non-compliance, and VAT Rate. The rest $37 \%$ is explained by other factors in the VAT collection performance not studied in this research. Further, the adjusted R-square $=0.62$ shows that, the factors accounted for $62 \%$ of the variance in VAT collection performance.

Regression results in table 4.30.below indicated the coefficient for each of the variables as well as their significance levels in the model. As shown, Tax payer's awareness of VAT, Tax payer's maintenance of account, Tax Evasion, Tax Avoidance, Tax Non-compliance and VAT rate were determinants influence significantly VAT collection performance. 
Table4.26.Regression Analysis Result of Tax payers

\begin{tabular}{|c|c|c|c|c|c|c|}
\hline Source & SS & \multicolumn{2}{|c|}{ MS } & & \multirow{2}{*}{$\begin{array}{l}\text { Number of obs } \\
F(6,217)\end{array}$} & 224 \\
\hline & & \multirow{2}{*}{\multicolumn{2}{|c|}{29.0705131}} & & & 62.78 \\
\hline Model & 174.423079 & & & & Prob $>$ F & 0.0000 \\
\hline Residual & 100.483171 & \multicolumn{2}{|c|}{.463056088} & & R-squared & 0.6345 \\
\hline & & \multirow{2}{*}{\multicolumn{2}{|c|}{$223 \quad 1.23276345$}} & & Adj R-squared & 0.6244 \\
\hline Total & 274.90625 & & & & Root MSE & 0.68048 \\
\hline $\mathrm{VCP}$ & Coef. & Std. Err. & $\mathrm{T}$ & $\mathrm{P}>\mathrm{t}$ & [95\% Conf. & Interval] \\
\hline TPAWOV & 0.589327 & .076338 & 7.72 & 0.000 & 0.4388681 & 0.7397859 \\
\hline TPMOA & 0.2676162 & .0575833 & 4.65 & 0.000 & 0.1541219 & 0.3811104 \\
\hline $\mathrm{TE}$ & -0.2949911 & .0472801 & -6.24 & 0.000 & -0.388178 & -0.201804 \\
\hline TA & -0.1172322 & .0425007 & -2.76 & 0.006 & -0.2009993 & -0.033465 \\
\hline TNCOM & -0.1379408 & .0315532 & -4.37 & 0.000 & -0.2001309 & -0.075751 \\
\hline VR & 0.1028467 & .0481774 & 2.13 & 0.034 & 0.007891 & 0.1978023 \\
\hline cons & 2.616567 & .3444459 & 7.60 & 0.000 & 1.937679 & 3.295455 \\
\hline
\end{tabular}

Source: primary data, STATA output 2018

The regression equation for Tax payer's variables was:

VCP $\mathrm{i}=\alpha 0+\beta 1 T P A W O V \mathrm{i}+\beta 2$ TPMOA $\mathrm{i}+\beta 3 \mathrm{TE} \mathrm{i}+\beta 4 \mathrm{TA} \mathrm{i}+\beta 5 \mathrm{TNCOM} \mathrm{i}+\beta 6 \mathrm{VR} \mathrm{i}+\varepsilon \mathrm{i}$

VCP $\mathrm{i}=2.6165+0.5893$ TPAWOV +0.2676 TPMOA -0.2949 TE -0.1172 TA-0.1379TNCOM $+0.1028 V R+\varepsilon i$

Moreover, the model summery also shows the significance of the model by the $\mathrm{P}$ value statistics $(\mathrm{P}=0.000)$ and $\mathrm{F}=62.78$ makes known the sound explanatory power of the model. This statistics indicates that the overall model is significant in explaining the dependent variable since the associated probability is lower than 0.05 . It also suggests that the relationship between the dependent variable and independent variables is linear. The beta $(\beta)$ sign also shows the positive or negative effect of the independent variables coefficient over the dependent variable.

The findings shows that when Tax payer's awareness of VAT increase, VAT collection performance increase by $58.93 \%$ by controlling other factors constant. When Tax payer's maintenance of account increase, VAT collection performance increase by $26.76 \%$ by controlling other factors constant. When Tax Evasion increase, VAT collection performance decrease by $29.49 \%$ by controlling other factors constant. When Tax avoidance increase, VAT collection performance decrease by $11.72 \%$ by controlling other factors constant. When Tax Non-Compliance increase, VAT collection performance decrease by $13.79 \%$ by controlling other factors constant. When VAT rate increase, VAT collection performance increase by $10.28 \%$ by controlling other factors constant. This implies that Tax payers awareness of VAT, Tax payers maintenance of account and VAT rate have a positive relationship with VAT collection performance and statistically significant $(\mathrm{P}$-value $=0.000$, 0.000 and 0.034 respectively, refers to less than 0.05). But Tax Evasion, Tax Avoidance, Tax Non-Compliance have a negative relationship with VAT collection performance and statistically significant $(\mathrm{P}$-value $=0.000$, 0.006 and 0.000 respectively, refers to less than 0.05 ). All variables related to Tax payers ; (Tax payer's awareness of VAT, Tax payer's maintenance of account, Tax Evasion, Tax avoidance, Tax non-compliance and VAR rate) are found significantly influencing VAT collection performance in the study area.

\section{Model summery related to Institutional variables}

The regression results indicated the goodness of fit for the regression between independent variables and dependent variables was satisfactory in the multiple regressions. An R squared of 0.78 indicates that $78 \%$ of the relationship is explained by the identified seven factors namely VAT assessment, Adequate Manpower, VAT audit, competency training, Tax payer's identification, External legal environment and penalization. The rest $22 \%$ is explained by other factors in the VAT collection performance not studied in this research. Further, the adjusted R-square $=0.76$ shows that, the factors accounted for $76 \%$ of the variance in VAT collection performance. 
Table 4.27 Result of Regression Analysis of Institutional variables

\begin{tabular}{|c|c|c|c|c|c|c|}
\hline \multirow[t]{2}{*}{ Source } & \multicolumn{4}{|c|}{ SS $\quad$ df $\quad$ MS } & \multirow{2}{*}{$\begin{array}{l}\text { Number of } \\
\text { obs } \\
F(7,66)\end{array}$} & \multirow{2}{*}{$\begin{array}{r}74 \\
34.22\end{array}$} \\
\hline & & & & & & \\
\hline Model & 64.5085887 & 7 & 9.21551268 & & Prob $>$ F & 0.0000 \\
\hline Residual & 17.7726613 & 66 & .269282747 & & R-squared & 0.7840 \\
\hline & & & & & squared & 0.7611 \\
\hline Total & 82.28125 & $73 \quad 1.1271$ & 14041 & & Root MSE & 0.51892 \\
\hline $\mathrm{VCP}$ & Coef. & Std. Err. & $\mathrm{T}$ & $\mathrm{P}>\mathrm{t}$ & [95\% Conf. & Interval] \\
\hline VA & .1567516 . & .0770871 & 2.03 & 0.046 & 0.0028423 & 0.3106609 \\
\hline VAUD & .1316395 . & .0619087 & 2.13 & 0.037 & 0.0080349 & 0.2552442 \\
\hline COMT & .2294825 & .0719567 & 3.19 & 0.002 & 0.0858164 & 0.3731486 \\
\hline AMAP & . & .0626893 & 3.53 & 0.001 & 0.0962254 & 0.3465521 \\
\hline TPI & .3512753 & .0703628 & 4.99 & 0.000 & 0.2107914 & 0.4917592 \\
\hline ELE & -.1509557 & .0598732 & -2.52 & 0.014 & -0.2704963 & -0.0314151 \\
\hline PEN & .3792096 & .134079 & 2.83 & 0.006 & 0.1115122 & 0.6469071 \\
\hline cons & -.9332123 & .7334944 & -1.27 & 0.208 & -2.397681 & 0.5312566 \\
\hline
\end{tabular}

Source: primary data, STATA output 2018

The regression equation for Authority employee's variables was:

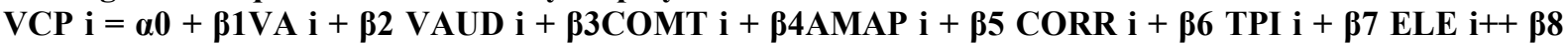
PEN i+ \&i

VCP $\mathrm{i}=-0.9332+0.1567 \mathrm{VA}+0.1316 \mathrm{VAUD}+0.2294$ COMT +0.2213AMAP+0.3512TPI-0.1509ELE+0.3792

PEN + \&i

Moreover, the model summery also shows the significance of the model by the $\mathrm{P}$ value statistics $(\mathrm{P}=0.000)$ and $\mathrm{F}=34.22$ makes known the sound explanatory power of the model. This statistics indicates that the overall model is significant in explaining the dependent variable since the associated probability is lower than 0.05.It also suggests that the relationship between the dependent variable and independent variables is linear. The findings show that when frequency of VAT Assessment increase, VAT collection performance increase by $15.67 \%$ by controlling other factors constant. When frequency of VAT audit increase, VAT collection performance increase by $13.16 \%$ by controlling other factors constant. When frequency of training increases, VAT collection performance increase by $22.94 \%$ by controlling other factors constant. When adequate manpower increase, VAT collection performance increase by $22.13 \%$ by controlling other factors constant. When Tax payers Identification increase, VAT collection performance increase by $35.12 \%$ by controlling other factors constant. When External legal Environment increases, VAT collection performance decreases by $15.09 \%$ by controlling other factors constant. When Penalization increases by, VAT collection performance increases by $37.92 \%$ by controlling other factors constant. This implies that VAT Assessment, VAT Auditing, Competence training, Adequate manpower, Tax payers identification and Penalization have a positive relationship with VAT collection performance and statistically significant in explaining VAT collection performance as $p$ value $=0.046$, $0.037,0,002,0.001,0.000$ and 0.006 respectively. But External legal environment has a negative relationship with VAT collection performance and statistically significant in explaining VAT collection performance as $p$ value 0.014. Among the independent variables, Tax payer's identification has been found to be the most determinant and statistically significant.

\section{In-depth interview results}

The interviews were conducted by using semi-structured interview method to reach five VAT Administrations starting from Oromia Revenues Authority Assessment and follow up department head to woreda level. These were; Oromia Revenues Authority Assessment and follow-up department head (1), West Shoa Zone Revenue Authority Assessment and follow-up department head (1), Assessment and follow-up department heads of selected three woredas (3) were interviewed at different times.

There are tax payers yet to be registered for VAT but Revenue Authority so far not included, what are the reasons. They responded that many reasons, some of them are: lack of man power and resources, Tax payers not tell their exact annual income, lack of commitment of some employees at different level to identify tax payers, 
political pressure, lack of awareness of VAT, biased of employees and the instability of external part.

In-depth interview were asked about what are mechanisms for raising objections against penalties by tax payers in handling their grievances. Their responses were similar to the procedures written on proclamation. Appeal is made according to a constitutional right as far as the law. The VAT system is not exception to these rules. A tax payer under VAT, Who is aggrieved by the decision of tax authorities, may lodge his complaint to a body competent to hear and decide on such application. The aggrieved parts have two options: tax appeal committee or regular courts. The tax payer objecting the assessment by revise committee while taking appeal to Tax Appeal Committee is required to deposit $50 \%$ of the additional tax assessed. Then the committee gives the decision based on VAT proclamation. If Tax payers satisfied with decision given by committee the appeal can finalized at this stage unless go for regular courts.

For the interview question how the administrative officials are handling the challenges of VAT Levy and Collection by using appropriate VAT Management Techniques, The interviewee suggested that first we identify the areas of the problems. Then we discussed with committee and give the direction to solution. This means that make awareness creation to Tax payers, Employees and society as all. According to Oromia assessment and Follow up department leader said that there is person to do on VAT assessment and collection. In addition to we call other employees from different Zone to make operation side used as best techniques.

On what are the criteria used by the authority for sample selection of tax payers for audit and audit procedures. They responded that we follow audit criteria which are comprehensive and sample audit that have 13 points procedure. By using SIGTAS if the summation of thirteen point procedures greater than fifteen we used comprehensive audit and if the summation of thirteen point procedures less than fifteen we used sample audit. But according to west Shoa Zone assessment and Follow up department leader suggested that not follow this procedures rather used based on the year of VAT registered Tax payers. The first VAT registered Tax payers audited first.

Another question what are the major problems in relation to the assessment and collection of VAT were interviewed. The major problems they raised were lack of manpower and interruption of SIGTAS. Especially from the three selected woredas assessment and Follow up department leaders point of view there is no Auditor at woreda level to audit VAT registered Tax payer's document. Finally for what is the reason consumers are not willing to buy goods and services with VAT. They suggested that due to lack of consumers awareness of VAT, due to all Tax payers not registered for VAT and Consumers are interested to buy goods or services from nonregistered enterprise to get lower Price.

\section{Conclusions}

The study covered the interaction between Value Added Tax collection performance and exploratory variables of Tax payers (Tax payer's awareness of VAT, Tax payer's maintenance of account, Tax Evasion, Tax Avoidance, Tax Non-compliance, and VAT Rate) and Institutional variables (VAT assessment, Manpower, VAT audit, competency training, Tax payer's identification, External legal environment and penalization).The main objective of the study was to evaluate the determinants of VAT collection performance in West Shoa Zone. The researchers used quantitative and qualitative research approach and primary and secondary data type. Survey design was used with questionnaire and semi- structured interview as tool of data collection. In this study both purposive and stratification sampling techniques were used. The study analysis was used the descriptive statistics, Pearson correlation matrix and ordinary least square (OLS) estimation method. The outcome of regression result shows that classical linear regression model assumptions were not violated.

According to Pearson correlation result of Tax payers variables shows that Tax payer's awareness of VAT, Tax payer's maintenance of account and VAT Rate were positive correlated with VAT collection performance. Moreover, the coefficient estimates of correlation was $0.622,0.5205$ and 0.1837 from highest to lowest $\rho<0.05$ respectively. While Tax Evasion, Tax Avoidance and Tax Non-compliance were negative correlated to VAT collection performance with coefficient estimates of correlation was $-0.5471,-0.3984$ and $-0.2854, \rho<0.05$ respectively. On the other hand Pearson correlation result of Institutional variables shows that variables (Tax payers identification, Competence training, VAT assessment, VAT audit and Adequate manpower ) were positive and significantly correlated with VAT collection performance ( $\mathrm{r}=0.7197,0.7480,0.6294$, $0.5145,0.3463, \rho<0.05$ respectively). But, two variables (External legal environment and penalization) were negative and significantly correlated with VAT collection performance $(r=-0.3203,-0.2455, \rho<0.05$ respectively). In general it's concluded that Value added tax have a great contribution in increasing government revenues, Hence the government authority/tax office has to focused on factors which negatively affect VAT and needs to take a corrective actions.

\section{References}

Alemayehu B (2010). An Examination of the Link between Tax Administration and Value Added Tax Compliance in Ethiopia. 
Ebrill L, Keen M, Bodin, JP, \& Summers, V (2001). The modem VAT. Washington, IMF Publication Services.

Hailemariam M (2011). Implementation of Value Added Tax and Its Related Problems In Ethiopia" (The Case Of ERCA), Addis Ababa University School Of Business And Public Administration MBA Program.

Arega H (2004). "Assessment on the VAT implementation in Ethiopia" IMF, Report on the Evaluation of the Role of the IMF in Argentina, 1991-2001.

James S, and Nobes C (2000). The Economics of taxation: principles, policy and Practice $7^{\text {th }}$ ed. Prentice-Hall.

John W, Creswell (2003). Research Design Qualitative, Quantitative, and mixed methods approaches, 2nd Ed.

Jones S, \& Rhoades S (2011). Principles of Taxation for Business and Investment Planning, McGraw-Hill Companies, Inc.

Kaplow L, (2010). The Theory of Taxation and Public Economics. Princeton University Press.

Mikesell JL, (2007). Developing options for the administration of local taxes: An international review. Public Budgeting \& Finance, 27(1), 41-68.

Misrak T (2008). Ethiopian Tax Accounting: Theory and Practice. Addis Ababa, Ethiopia.

Mohd Nornadiah, Razali and Yap Bee Wah (2011). Power comparisons of shapiro-wilk, kolmogorov-smirnov, lilliefors andAnderson-darling tests, Journal of statistical modeling and analytics 2, no.1, 21-33.

Saleemi NA, (2005). Taxation I Simplified.5th ed. Saleemi Publications Limited

Sanni A (2012). Current law and practice of value added tax in Nigeria. British Journal of Arts and Social Sciences, 5(2), 186-201.

Soyode L and Kajola SO, (2006). Taxation, Principles and Practice in Nigeria.

Teffera AH, (2004). Assessment of the value added tax implementation in Ethiopia, In Second International Conference on the Ethiopian Economy. Addis Ababa, Ethiopia.

Worku G (2008). Tax accounting in Ethiopia. (2nd Edition) Addis Ababa, Ethiopia.

Yesegat WA, (2008). Value added tax administration in Ethiopia: a reflection of problems. 